\title{
Determinants of farmers' choice of adaptation methods to climate change in the Nile Basin of Ethiopia
}

\author{
Temesgen Tadesse Deressa ${ }^{\mathrm{a}, *}$, Rashid M. Hassan ${ }^{\mathrm{b}, 1}$, Claudia Ringler ${ }^{\mathrm{c}, 2}$, Tekie Alemu ${ }^{\mathrm{d}}$, Mohamud Yusuf ${ }^{\mathrm{d}}$ \\ ${ }^{a}$ Centre for Environmental Economics and Policy in Africa (CEEPA), Department of Agricultural Economics E' Rural Development, University of Pretoria, RSA, Room 2-4, \\ Agric. Annexe, Pretoria 0002, South Africa \\ ${ }^{\mathrm{b}}$ Centre for Environmental Economics and Policy in Africa (CEEPA), Department Agricultural Economics, Faculty of Natural and Agricultural Sciences, \\ University of Pretoria, Room 2-6, Agric. Annexe, Pretoria 0002, South Africa \\ ${ }^{\mathrm{c}}$ Environment and Production Technology Division, International Food Policy Research Institute, 2033 K Street, NW, Washington, DC 20006-1002, USA \\ ${ }^{\mathrm{d}}$ Ethiopian Development Research Institute (EDRI), Addis Ababa, Ethiopia
}

\section{A R T I C L E I N F O}

\section{Article history:}

Received 13 January 2008

Received in revised form 30 October 2008

Accepted 19 January 2009

Keywords:

Adaptation

Perception

Climate change

Nile Basin of Ethiopia

\begin{abstract}
A B S T R A C T
This study identifies the major methods used by farmers to adapt to climate change in the Nile Basin of Ethiopia, the factors that affect their choice of method, and the barriers to adaptation. The methods identified include use of different crop varieties, tree planting, soil conservation, early and late planting, and irrigation. Results from the discrete choice model employed indicate that the level of education, gender, age, and wealth of the head of household; access to extension and credit; information on climate, social capital, agroecological settings, and temperature all influence farmers' choices. The main barriers include lack of information on adaptation methods and financial constraints.
\end{abstract}

(c) 2009 Elsevier Ltd. All rights reserved.

\section{Introduction}

Studies indicate that Africa's agriculture is negatively affected by climate change (Pearce et al., 1996; McCarthy et al., 2001). Adaptation is one of the policy options for reducing the negative impact of climate change (Adger et al., 2003; Kurukulasuriya and Mendelsohn, 2008). Adaptation to climate change refers to adjustment in natural or human systems in response to actual or expected climatic stimuli or their effects, which moderates harm or exploits beneficial opportunities (IPCC, 2001). Common adaptation methods in agriculture include use of new crop varieties and livestock species that are better suited to drier conditions, irrigation, crop diversification, adoption of mixed crop and livestock farming systems, and changing planting dates (Bradshaw et al., 2004; Kurukulasuriya and Mendelsohn, 2008; Nhemachena and Hassan, 2007).

Agriculture is the main sector of the Ethiopian economy. It contributes about $52 \%$ of the GDP, generates more than $85 \%$ of the

\footnotetext{
* Corresponding author. Tel.: +27 12420 5767/722324920 (Cell); fax: +27 124204958 .

E-mail addresses: ttderessa@yahoo.com (T.T. Deressa), rashid.hassan@up.ac.za (R.M. Hassan), C.ringler@cgiar.org (C. Ringler), tekiealemu@yahoo.com (T. Alemu), mahmudyesuf@yahoo.com (M. Yusuf).

1 Tel.: +27 12420 3317; fax: +27 124204958

2 Tel.: + 1202862 8137; fax: +1 2022464439 .
}

foreign exchange earnings, and employs about $80 \%$ of the population (CSA, 2004). Despite its high contribution to the overall economy, this sector is challenged by many factors, of which climate-related disasters like drought and flood (often causing famine), are the major ones (Deressa, 2007). Knowledge of the adaptation methods and factors affecting farmers' choices enhances policies directed toward tackling the challenges that climate change is imposing on Ethiopian farmers.

Studies have been undertaken to measure the impact of climate change on Ethiopian agriculture (Deressa, 2007; NMSA, 2001; Kidane et al., 2006) and water resources (Kinfe, 1999; Lijalem et al., 2006; Deksyos and Abebe, 2006). The studies on agriculture analyzed the monetary or yield impact of climate change and suggested adaptation measures but failed to indicate the factors affecting the choice of the suggested adaptation methods. This presents an important limitation since farmers' responses to climate change or their choice of adaptation methods is dictated by a host of socio economic and environmental factors. The knowledge of these socioeconomic and environmental factors assists policy to strengthen adaptation through investing on these factors.

Other studies have attempted to analyze the impact of climate change and factors affecting the choice of adaptation methods in crop, livestock and mixed crop livestock production systems in Africa at regional level (Maddison, 2006; Kurukulasuriya and Mendelsohn, 2008; Seo and Mendelsohn, 2008; Hassan and Nhemachena, 2008). Results from these studies are highly 
aggregated and the parameter estimates have little importance in identifying country specific impacts and adaptation methods given the heterogeneity of countries included. Additionally, other factors that are believed to affect adaptation such as social capital (Boko et al., 2007) and agro ecological features were not addressed in these studies.

Therefore, the objective of this study is to analyze the factors affecting the choice of adaptation methods in crop production systems by taking the case of farmers in the Nile basin of Ethiopia to bridge this gap of knowledge in order to guide policymakers on ways to promote adaptation. This paper is organized as follows: Section 2 discusses the adaptation strategies of farmers in the Nile basin of Ethiopia. Section 3 describes the empirical model. Section 4 presents the study area, data and empirical specification of model variables. Section 5 discusses model results and Section 6 presents conclusions and policy implications.

\section{Adaptation strategies of farmers in the Nile Basin of Ethiopia}

Based on the cross-sectional household survey data collected from 1000 households during 2004/2005 production season in the Nile basin of Ethiopia, this section briefly summarizes farmers' perceptions of climate change and the strategies they consider appropriate to these changes. Detailed descriptions of a sample of 1000 farm household surveys are given Section 4. The surveyed farm households were asked questions about their observations in the patterns of temperature and rainfall over the past 20 years.

The results indicate that $50.6 \%$ of the surveyed farmers have observed increasing temperature over the past 20 years were as $53 \%$ of them have observed decreasing rainfall over the past 20 years (Table 1). Additionally, these farmers who claimed to have observed changes in climate over the past 20 years were subsequently asked if they have responded through adaptation to counteract the impact of the climate change. Accordingly, those who responded that they have adapted to climate change indicate different adaptation strategies which include planting trees, soil conservation, use of different crop varieties, changing planting dates and irrigation (Table 2). The use of different crop varieties is the most commonly used method, whereas use of irrigation is the adaptation least practiced among the major adaptation methods identified in the Nile Basin of Ethiopia. Greater use of different crop varieties as an adaptation method could be associated with the lower expense and ease of access by farmers, while the limited use of irrigation could be attributed to the need for more capital and low potential for irrigation. These adaptation measures mentioned by Ethiopian farmers are similar to the other findings in the climate change adaptation literature (Bradshaw et al., 2004; Kurukulasuriya and Mendelsohn, 2008; Maddison, 2006; Nhemachena and Hassan, 2007; Hassan and Nhemachena, 2008). Moreover, farmers who did not adapt have given many reasons for their failures to adapt which include lack of information, lack of money, shortage of labour, shortage of land, and poor potential for irrigation (Fig. 1).

Table 1

Farmers' perception of long-term temperature and precipitation changes.

\begin{tabular}{ll}
\hline Variable & Percent of respondents \\
\hline (a) Temperature & \\
Temperature increased & 50.6 \\
Temperature decreased & 1.9 \\
Temperature stayed the same & 14.4 \\
(b) Precipitation & \\
Precipitation increased & 10.4 \\
Precipitation decreased & 53 \\
Precipitation stayed the same & 12 \\
Number of respondents & 995 \\
\hline
\end{tabular}

Table 2

Farmers' adaptation strategies.

\begin{tabular}{lc}
\hline Variable & Percent of respondents \\
\hline No adaptation & 42 \\
Planting trees & 21 \\
Soil conservation & 15 \\
Different crop varieties & 13 \\
Early and late planting & 5 \\
Irrigation & 4 \\
Total number of respondents & 830 \\
\hline
\end{tabular}

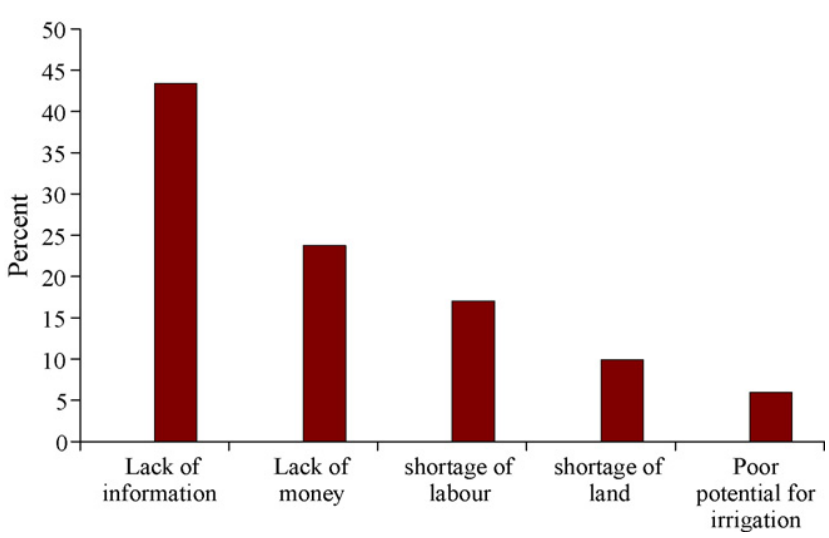

Fig. 1. Barriers to adaptation.

\section{Empirical model}

The multinomial logit (MNL) model is used to analyse the determinants of farmers' choice of adaptation strategies in the Nile basin of Ethiopia. This method can be used to analyze crop (Kurukulasuriya and Mendelsohn, 2008; Hassan and Nhemachena, 2008) and livestock (Seo and Mendelsohn, 2008) choices as methods to adapt to the negative impacts of climate change. The advantage of the MNL is that it permits the analysis of decisions across more than two categories, allowing the determination of choice probabilities for different categories (Madalla, 1983; Wooldridge, 2002) and it is also computationally simple (Tse, 1987).

To describe the MNL model, let $y$ denote a random variable taking on the values $\{1,2, \ldots, J\}$ for $J$, a positive integer, and let $\mathbf{x}$ denote a set of conditioning variables. In this case, $y$ denotes adaptation options or categories and $\mathbf{x}$ contain different household, institutional and environmental attributes (described in Section 4). The question is how cetirus paribus changes in the elements of $\mathbf{x}$ affect the response probabilities $(P(y=j / x), j=1,2, \ldots, J$. Since the probabilities must sum to unity, $P(y=j / x)$ is determined once we know the probabilities for $j=2, \ldots, J$.

Let $\mathbf{x}$ be a $1 \times K$ vector with first element unity. The MNL model has response probabilities:

$P(y=j \mid x)=\frac{\exp \left(x \beta_{j}\right)}{\left[1+\sum_{h=1}^{J} \exp \left(x \beta_{h}\right), j=1, \ldots, J\right]}$

where $B_{j}$ is $K \times 1, j=1, \ldots, J$.

For this study, the adaptation options or response probabilities are six as described in the above section (Table 2 ).

Unbiased and consistent parameter estimates of the MNL model in Eq. (1) require the assumption of independence of irrelevant alternatives (IIA) to hold. More specifically, the IIA assumption requires that the probability of using a certain adaptation method by a given household needs to be independent from the probability of choosing another adaptation method (that 
Table 3

Description of the independent variables.

\begin{tabular}{|c|c|c|c|}
\hline Explanatory variable & Mean & S.D. & Description \\
\hline Years of education & 1.7035 & 2.7777 & Continuous \\
\hline Size of household & 6.1493 & 2.2206 & Continuous \\
\hline Gender of the head of household & 0.8963 & 0.3051 & Dummy, takes the value of 1 if male and 0 otherwise \\
\hline Age of the head of household & 44.2915 & 12.6248 & Continuous \\
\hline Farm income & 4374.7610 & 7018.6360 & Continuous \\
\hline Nonfarm income & 218.2594 & 790.9987 & Continuous \\
\hline Livestock ownership & 0.9488 & 0.2205 & Dummy takes the value of 1 if owned and 0 otherwise \\
\hline Extension on crop and livestock & 0.5455 & 0.4982 & Dummy, takes the value of 1 if visited and 0 otherwise \\
\hline Information on climate change & 0.3731 & 0.4839 & Dummy takes the value of 1 if there is and 0 otherwise \\
\hline Farmer-to-farmer extension & 0.4833 & 0.5000 & Dummy takes the value of 1 if there is and 0 otherwise \\
\hline Credit & 0.2191 & 0.4138 & Dummy takes the value of 1 if there is access and 0 otherwise \\
\hline Number of relatives in got & 13.3725 & 19.4420 & Continuous \\
\hline Farm size in hectares & 2.02 & 1.18 & Continuous \\
\hline Distance to output market in kilometres & 5.70 & 4.14 & Continuous \\
\hline Distance to input market in kilometres & 5.61 & 4.22 & Continuous \\
\hline Local agroecology kola (lowlands) & 0.25 & 0.43 & Dummy takes the value of 1 if kola and zero otherwise. \\
\hline Local agroecology weynadega (midlands) & 0.50 & 0.50 & Dummy takes the value of 1 if weynadega and zero otherwise. \\
\hline Local agroecology dega (highlands) & 0.25 & 0.43 & Dummy takes the value of 1 if $\operatorname{deg} a$ and zero otherwise. \\
\hline Temperature & 18.61 & 1.34 & Continuous, annual average over the $2004-2005$ survey period \\
\hline Precipitation & 115.64 & 35.57 & Continuous, annual average over the 2004-2005 survey period \\
\hline
\end{tabular}

is, $P_{j} / P_{k}$ is independent of the remaining probabilities). The premise of the IIA assumption is the independent and homoscedastic disturbance terms of the basic model in Eq. (1). The parameter estimates of the MNL model provide only the direction of the effect of the independent variables on the dependent (response) variable, but estimates do not represent either the actual magnitude of change nor probabilities. Differentiating Eq. (1) with respect to the explanatory variables provides marginal effects of the explanatory variables given as

$\frac{\partial P_{j}}{\partial x_{k}}=P_{j}\left(\beta_{j k}-\sum_{J=1}^{J-1} P_{j} \beta_{j k}\right)$

The marginal effects or marginal probabilities are functions of the probability itself and measure the expected change in probability of a particular choice being made with respect to a unit change in an independent variable from the mean (Green, 2000).

\section{Study area, data and empirical specification of model variables}

The study area for this research is the Nile Basin of Ethiopia, which covers a total area of about 358,889 square kilometres, equivalent to $34 \%$ of the total geographic area of the country. Moreover, about $40 \%$ of the population of Ethiopia lives in this basin. The basin covers six regional states of Ethiopia in different proportions: $38 \%$ of the total land area of Amhara, 24\% of Oromiya, $15 \%$ of Benishangul-Gumuz, $11 \%$ of Tigray, $7 \%$ of Gambella, and 5\% of Southern Nations Nationalities and Peoples (SNNP) Regional States (MoWR, 1998).

This basin consists of three major rivers: the Abbay River, which originates in the central highlands; Tekeze River, which originates in the northwest; and Baro-Akobo River, which originates in the southwestern part of the country. The total annual surface runoff of the three rivers is estimated at 80.83 billion cubic meters per year, which amounts to nearly 74 of Ethiopia's 12 river basins (MoWR, 1998).

Ethiopia has four traditional agro ecological zones. These are Bereha (desert, below $500 \mathrm{~m}$ a.s.l.), Kolla (low land, 500-1500 m a.s.l.), Weynadega (middle land, 1500-2500 $\mathrm{m}$ a.s.l.) and Dega (highland, 2500-3500 $\mathrm{m}$ a.s.l.). Out of the four traditional agro ecological settings of Ethiopia, the survey districts fall in three of them (Dega, Weynadega, Kolla).
The International Food Policy Research Institute (IFPRI) in collaboration with the Ethiopian Development Research Institute (EDRI) collected the data for this study. A cross-sectional household survey of farmers was conducted during the 2004/2005 production year in the Nile Basin of Ethiopia. The household survey covered five regional states of Ethiopia, 20 districts, and 1000 households. The sample districts were purposely selected to include different attributes of the basin, including the traditional typology of agroecological zones in the country, the degree of irrigation activity (percent of cultivated land), average annual rainfall, rainfall variability, and vulnerability (the food aiddependent population).

Peasant associations (administrative units smaller than districts) were also purposely selected to include households that irrigate their farms. One peasant association is selected from every district, making a total of 20 each. Once the peasant associations were chosen, 50 farmers were randomly selected from each peasant association, making 1000 the total number of households interviewed. The temperature and rainfall data for the surveyed seasons were obtained from the IFPRI.

The dependent variable in the empirical estimation is the choice of an adaptation option from the set of adaptation measures listed in Table 2 . The choice of the explanatory variables is based on data availability and literature. The explanatory variables for this study include household characteristics such as education, gender, age of the household head, household size, farm and nonfarm income, and livestock ownership; institutional factors such as extension services on crop and livestock production, information on climate, access to credit, social capital, which includes farmer-to-farmer extension services and the number of relatives in the "Got," 3 the local area, and agroecological characteristics such as temperature and rainfall. Table 3 gives the descriptions of the explanatory variables used for our estimation. Moreover, hypothesis on how the explanatory variables influence adaptation to climate change are presented below.

Higher level of education is believed to be associated with access to information on improved technologies and higher productivity (Norris and Batie, 1987). Evidence from various sources indicates that there is a positive relationship between the education level of the household head and the adoption of improved technologies (Igoden et al., 1990; Lin, 1991) and adaptation to climate change (Maddison, 2006). Therefore, farmers

\footnotetext{
3 "Got" means "a local place."
} 
with higher levels of education are more likely to adapt better to climate change.

Male-headed households are more likely to get information about new technologies and undertake risky businesses than female-headed households (Asfaw and Admassie, 2004). Moreover, Tenge and Hella (2004) argue that having a female head of household may have negative effects on the adoption of soil and water conservation measures, because women may have limited access to information, land, and other resources due to traditional social barriers. A study by Nhemachena and Hassan (2007) finds contrary results, arguing that female-headed households are more likely to take up climate change adaptation methods. The authors conclude that women are more likely to adapt because they are responsible for much of the agricultural work in the region and therefore have greater experience and access to information on various management and farming practices. Thus, the adoptions of new technologies or adaptation methods appear to be rather context specific.

Age of the head of household can be used to capture farming experience. On the one hand, studies in Ethiopia have shown a positive relationship between number of years of experience in agriculture and the adoption of improved agricultural technologies (Kebede et al., 1990), while a study by Shiferaw and Holden (1998) indicates a negative relationship between age and adoption of improved soil conservation practices. On the other hand, studies by Maddison (2006) and Nhemachena and Hassan (2007) indicate that experience in farming increases the probability of uptake of adaptation measures to climate change. This study hypothesizes that experience increases the probability of adapting to climate change.

The influence of household size on use of adaptation methods can be seen from two angles. The first assumption is that households with large families may be forced to divert part of the labor force to off-farm activities in an attempt to earn income in order to ease the consumption pressure imposed by a large family (Yirga, 2007). The other assumption is that large family size is normally associated with a higher labor endowment, which would enable a household to accomplish various agricultural tasks. For instance, Croppenstedt et al., 2003 argue that households with a larger pool of labor are more likely to adopt agricultural technology and use it more intensively because they have fewer labor shortages at peak times. Here it is expected that households with large families are more likely to adapt to climate change.

Farm and nonfarm income and livestock ownership represent wealth. It is regularly hypothesized that the adoption of agricultural technologies requires sufficient financial wellbeing (Knowler and Bradshaw, 2007). Other studies that investigate the impact of income on adoption found a positive correlation (Franzel, 1999). Higher income farmers may be less risk averse and have more access to information, a lower discount rate, and a longer term planning horizon (CIMMYT, 1993).

Livestock plays a very important role by serving as a store of value and by providing traction (especially oxen) and manure required for soil fertility maintenance (Yirga, 2007). Thus, for this study, farm and nonfarm income and livestock ownership are hypothesized to increase adaptation to climate change.

Extension on crop and livestock production and information on climate represent access to the information required to make the decision to adapt to climate change. Various studies in developing countries, including Ethiopia, report a strong positive relationship between access to information and the adoption behavior of farmers (Yirga, 2007), and that access to information through extension increases the likelihood of adapting to climate change (Maddison, 2006; Nhemachena and Hassan, 2007). Thus, this study also hypothesizes that access to information increases probability of adapting to climate change.
Availability of credit eases the cash constraints and allows farmers to buy purchased inputs such as fertilizer, improved crop varieties, and irrigation facilities. Research on adoption of agricultural technologies indicates that there is a positive relationship between the level of adoption and the availability of credit (Yirga, 2007; Pattanayak et al., 2003). Likewise, this study also hypothesizes that there is a positive relationship between availability of credit and adaptation.

Social capital is represented by the number of relatives of a household in the local area and farmer-to-farmer extension. Informal institutions and private social networks play three distinct roles in adoption of agricultural technologies (Hogest, 2005, cited in Katungi, 2007). First, they act as conduits for financial transfers that may relax the farmer's credit constraints. Second, they act as conduits for information about new technology. Third, social networks can facilitate cooperation to overcome collective action dilemmas, where the adoption of technologies involves externalities. Isham (2002) shows that ethnically based and participatory social affiliations act as forms of social capital in the decision to adopt fertilizer. Thus, this study hypothesizes that social capital positively influences adaptation to change.

Studies on adoption of agricultural technologies indicate that farm size has both negative and positive effects on adoption, showing that the effect of farm size on technology adoption is inconclusive (Bradshaw et al., 2004). However, because farm size is associated with greater wealth, it is hypothesized to increase adaptation to climate change.

It is hypothesized that as distance to output and input markets increases, adaptation to climate change decreases. Proximity to market is an important determinant of adaptation, presumably because the market serves as a means of exchanging information with other farmers (Maddison, 2006).

It is also hypothesized that different households living in different agroecological settings use different adaptation methods. This is due to the fact that climatic conditions, soil, and other factors vary across different agroecologies, influencing farmers' perceptions of climate change and their decisions to adapt. Detailed analysis of the relationships between climatic variables such as temperature and rainfall and choice of adaptation methods requires time series data on how farmers have behaved over time in response to changing climatic conditions. As this type of data is not available for this study, it is assumed that cross-sectional variations can proxy temporal variations. Thus, the analysis includes controls for variations in temperature and rainfall across farm households over the 2004/ 2005 survey period.

\section{Model results and discussion}

The estimation of the multinomial logit model for this study was undertaken by normalizing one category, which is normally referred to as the "reference state," or the "base category." In this analysis, the first category (no adaptation) is the reference state.

In the initial run, farm size and distance to input and output markets were added to the model, but they were dropped, as they were not significant. Additionally, the MNL was run with and without the explanatory variables, such as extension on crop and livestock production and information on climate change and credit availability, assuming these variables to be endogenous, as they are in many studies. The results indicate that the inclusion of these variables does not significantly change the parameters of the estimates (the Hausman test has been employed to compare the models with and without these variables). Moreover, the Ordinary Least Square model was fitted and the model was tested for milticolliniarity using the variance inflation factor (VIF). The 
Table 4

Parameter estimates of the multinomial logit climate change adaptation model.

\begin{tabular}{|c|c|c|c|c|c|c|c|c|c|c|}
\hline \multirow[t]{2}{*}{ Explanatory variables } & \multicolumn{2}{|c|}{ Soil conservation } & \multicolumn{2}{|l|}{ Crop varieties } & \multicolumn{2}{|l|}{ Planting trees } & \multicolumn{2}{|c|}{ Changing planting date } & \multicolumn{2}{|l|}{ Irrigation } \\
\hline & Coefficients & $P$ level & Coefficients & $P$ level & Coefficients & $P$ level & Coefficients & $P$ level & Coefficients & $P$ level \\
\hline Education & $0.155^{* * *}$ & 0.003 & $0.115^{* *}$ & 0.017 & $0.139^{* * *}$ & 0.007 & $0.223^{* * *}$ & 0.000 & $0.217^{* *}$ & 0.011 \\
\hline Household size & 0.063 & 0.270 & 0.043 & 0.422 & 0.074 & 0.213 & -0.113 & 0.200 & 0.113 & 0.275 \\
\hline Gender of household head & $1.545^{* * *}$ & 0.002 & $1.238^{* * *}$ & 0.003 & $1.533^{* * *}$ & 0.003 & 1.265 & 0.121 & 1.277 & 0.133 \\
\hline Age of household head & 0.011 & 0.294 & 0.010 & 0.301 & $0.042^{* * *}$ & 0.000 & $0.025^{*}$ & 0.095 & $0.045^{* *}$ & 0.017 \\
\hline Farm income & $6.84 \mathrm{E}-05^{* * *}$ & 0.004 & $8.01 \mathrm{E}-05^{* * *}$ & 0.000 & $5.00 \mathrm{E}-07$ & 0.983 & $0.000109^{* * *}$ & 0.000 & $9.52 \mathrm{E}-05^{* * *}$ & 0.002 \\
\hline Nonfarm income & -0.00012 & 0.621 & $4.55 \mathrm{E}-05$ & 0.817 & $0.000315^{*}$ & 0.087 & $0.000358^{*}$ & 0.07 & 0.000314 & 0.153 \\
\hline Livestock ownership & 0.632 & 0.427 & -0.166 & 0.783 & 0.138 & 0.833 & 0.249 & 0.777 & $-2.054^{* *}$ & 0.011 \\
\hline Extension on crop and livestock & $0.765^{* *}$ & 0.028 & $0.987^{* * *}$ & 0.002 & $1.902^{* * *}$ & 0.000 & 0.466 & 0.373 & $1.380^{*}$ & 0.063 \\
\hline Information on climate change & 0.059 & 0.874 & $1.032^{* * *}$ & 0.001 & 0.173 & 0.604 & $0.839^{*}$ & 0.079 & $1.246^{* *}$ & 0.042 \\
\hline Farmer-to-farmer extension & $0.925^{* * *}$ & 0.007 & $1.234^{* * *}$ & 0.000 & $1.554^{* * *}$ & 0.000 & $1.323^{* *}$ & 0.012 & $1.544^{* *}$ & 0.011 \\
\hline Credit availability & $1.278^{* * *}$ & 0.000 & 0.487 & 0.112 & 0.392 & 0.231 & $1.213^{* * *}$ & 0.003 & $1.942^{* * *}$ & 0.000 \\
\hline Number of relatives in got & 0.008 & 0.341 & 0.010 & 0.220 & 0.002 & 0.814 & 0.013 & 0.247 & 0.003 & 0.803 \\
\hline Local agroecology klla & -0.055 & 0.881 & $-1.774^{* * *}$ & 0.000 & $-1.758^{* * *}$ & 0.000 & $-0.976^{*}$ & 0.055 & $-2.622^{* * *}$ & 0.001 \\
\hline Local agroecology dega & 0.495 & 0.154 & 0.352 & 0.254 & -0.353 & 0.334 & $0.958^{*}$ & 0.093 & -0.780 & 0.253 \\
\hline Temperature & $0.414^{* * *}$ & 0.000 & $0.445^{* * *}$ & 0.000 & 0.155 & 0.240 & $0.490^{* * *}$ & 0.001 & $0.571^{* * *}$ & 0.003 \\
\hline Precipitation & $-0.047^{* * *}$ & 0.000 & $-0.029^{* * *}$ & 0.000 & $-0.020^{* * *}$ & 0.000 & -0.003 & 0.719 & $-0.039^{* * *}$ & 0.000 \\
\hline Constant & $-8.064^{* * *}$ & 0.000 & $-8.939^{* * *}$ & 0.000 & $-7.009^{* * *}$ & 0.008 & $-15.315^{* * *}$ & 0.000 & $-13.515^{* * *}$ & 0.000 \\
\hline \multicolumn{11}{|l|}{ Diagnostics } \\
\hline Base category & \multicolumn{10}{|c|}{ No adaptation } \\
\hline Number of observations & \multicolumn{10}{|c|}{803} \\
\hline LR chi-square & \multicolumn{10}{|c|}{$648.24^{* * *}$} \\
\hline Log likelihood & \multicolumn{10}{|c|}{-901.62} \\
\hline Pseudo- $R^{2}$ & \multicolumn{10}{|c|}{0.26} \\
\hline
\end{tabular}

${ }^{* * *, * *, *}$ Significant at $1 \%, 5 \%$, and $10 \%$ probability level, respectively.

variance inflation factors for all variables are less than 10 (1.042.03), which indicate that multicollineraity is not a serious problem in this model.

Finally, the model was run and tested for the validity of the independence of the irrelevant alternatives (IIA) assumptions by using both the Hausman test for IIA and the seemingly unrelated postestimation procedure (SUEST). ${ }^{4}$ Both tests failed to reject the null hypothesis of independence of the climate change adaptation options, suggesting that the multinomial logit (MNL) specification is appropriate to model climate change adaptation practices of smallholder farmers ( $\chi^{2}$ ranged from -4.63 to 40.73 , with probability values ranging from 0.85 to 1.00 in the case of the Hausman test and $\chi^{2}$ ranging from 13.07 to 20.49 , with a $P$ value of $0.20-0.67$ in the case of SUEST). The estimated coefficients of the MNL model, along with the levels of significance, are presented in Table 4 . The likelihood ratio statistics as indicated by $\chi^{2}$ statistics are highly significant $(P<0.00001)$, suggesting the model has a strong explanatory power.

As indicated earlier, the parameter estimates of the MNL model provide only the direction of the effect of the independent variables on the dependent (response) variable: estimates do not represent actual magnitude of change or probabilities. Thus, the marginal effects from the MNL, which measure the expected change in probability of a particular choice being made with respect to a unit change in an independent variable, are reported and discussed. In all cases the estimated coefficients should be compared with the base category of no adaptation. Table 5 presents the marginal effects along with the levels of statistical significance.

\subsection{Education}

Education of the head of household increases the probability of adapting to climate change. As can be observed in Table 4, education significantly increases soil conservation and changing planting dates as an adaptation method. A unit increase in number

\footnotetext{
${ }^{4}$ SUEST is a generalization of the classical Hausman specification test useful for intramodel and cross-model hypothesis tests.
}

of years of schooling would result in a $1 \%$ increase in the probability of soil conservation and a $0.6 \%$ increase in change in planting dates to adapt to climate change. Moreover, almost all of the marginal values of education are positive across all adaptation options indicating the positive relationship between education and adaptation to climate change.

\subsection{Household size}

For most of the adaptation methods, increasing household size did not significantly increase the probability of adaptation, though the coefficient on the adaptation options has a positive sign. Even though it is not significant, it can be inferred that the larger the size of the household, the better the chance of adapting to climate change.

\subsection{Gender of the head of household}

The results indicate that male-headed households adapt more readily to climate change. Male-headed households were $7.6 \%$ more likely to plant trees and $2.4 \%$ more likely to change planting dates.

\subsection{Age of the household head}

Age of the household head, which represents experience, affected adaptation to climate change. For instance, a unit increase in age of the household head results in a 9\% increase in the probability of soil conservation, a $12 \%$ increase in changing of crop varieties, and a $10 \%$ increase in tree planting.

\subsection{Farm income}

The farm income of the households surveyed has a positive and significant impact on conserving soil, using different crop varieties, and changing planting dates. A unit increase in farm income increases these probabilities by less than $0.01 \%$. When the main source of income is farming and the amount of land for farming is limited, farmers tend to invest on productivity smoothening 
Table 5

Marginal effects from the multinomial logit climate change adaptation model.

\begin{tabular}{|c|c|c|c|c|c|c|c|c|c|c|c|c|}
\hline \multirow[t]{2}{*}{ Explanatory variables } & \multicolumn{2}{|c|}{ Soil conservation } & \multicolumn{2}{|l|}{ Crop varieties } & \multicolumn{2}{|l|}{ Planting trees } & \multicolumn{2}{|l|}{$\begin{array}{l}\text { Changing } \\
\text { date }\end{array}$} & \multicolumn{2}{|l|}{ Irrigation } & \multicolumn{2}{|l|}{ No adaptation } \\
\hline & Coefficients & $P$ level & Coefficients & $P$ level & Coefficients & $P$ level & Coefficients & $P$ level & Coefficients & $P$ level & Coefficients & $P$ level \\
\hline Education & $0.010^{*}$ & 0.066 & 0.007 & 0.321 & 0.008 & 0.144 & $0.006^{* *}$ & 0.013 & 0.002 & 0.123 & $-0.034^{* * *}$ & 0.000 \\
\hline Household size & 0.005 & 0.412 & 0.004 & 0.647 & 0.007 & 0.293 & $-0.006^{*}$ & 0.074 & 0.001 & 0.385 & -0.011 & 0.291 \\
\hline Gender of household head & $0.088^{* * *}$ & 0.004 & $0.116^{* *}$ & 0.019 & $0.096^{* * *}$ & 0.005 & 0.022 & 0.304 & 0.008 & 0.346 & $-0.330^{* * *}$ & 0.000 \\
\hline Age of household head & -0.0001 & 0.9010 & -0.0006 & 0.6990 & $0.0046^{* * *}$ & 0.000 & 0.001 & 0.350 & $0.0006^{*}$ & 0.0880 & $-0.0050^{* * *}$ & 0.0080 \\
\hline Farm income & $4.46 \mathrm{E}-06^{*}$ & 0.0720 & $1.09 \mathrm{E}-05^{* * *}$ & 0.0000 & $-5.44 \mathrm{E}-6^{* *}$ & 0.0400 & $3.36 \mathrm{E}-06^{* * *}$ & 0.000 & $1.00 \mathrm{E}-06^{* *}$ & 0.0490 & $-1.4 \mathrm{E}-05^{* * *}$ & 0.0000 \\
\hline Nonfarm income & $-2.5 \mathrm{E}-05$ & 0.2940 & $-4.84 \mathrm{E}-06$ & 0.8650 & $3.83 \mathrm{E}-05^{* *}$ & 0.0310 & $1.34 \mathrm{E}-05^{* *}$ & 0.049 & $4.22 \mathrm{E}-06$ & 0.1810 & $-2.6 \mathrm{E}-05$ & 0.5220 \\
\hline Livestock ownership & 0.070 & 0.184 & -0.030 & 0.781 & 0.027 & 0.6930 & 0.012 & 0.670 & -0.099 & 0.155 & 0.020 & 0.855 \\
\hline $\begin{array}{l}\text { Extension on crop } \\
\text { and livestock }\end{array}$ & 0.011 & 0.743 & 0.072 & 0.129 & $0.181^{* * *}$ & 0.000 & -0.009 & 0.659 & 0.011 & 0.318 & $-0.266^{* * *}$ & 0.000 \\
\hline $\begin{array}{l}\text { Information on } \\
\text { climate change }\end{array}$ & -0.042 & 0.201 & $0.176^{* * *}$ & 0.001 & -0.031 & 0.346 & 0.022 & 0.306 & 0.017 & 0.201 & $-0.142^{* *}$ & 0.021 \\
\hline $\begin{array}{l}\text { Farmer-to- farmer } \\
\text { extension }\end{array}$ & 0.021 & 0.525 & $0.113^{* *}$ & 0.017 & $0.120^{* * *}$ & 0.002 & 0.025 & 0.256 & 0.013 & 0.204 & $-0.291^{* * *}$ & 0.000 \\
\hline Credit availability & $0.129 * * *$ & 0.002 & -0.008 & 0.848 & -0.019 & 0.564 & $0.038^{*}$ & 0.099 & $0.038^{* *}$ & 0.039 & $-0.178^{* * *}$ & 0.000 \\
\hline Number of relatives in got & 0.0005 & 0.483 & 0.001 & 0.192 & -0.0004 & 0.640 & 0.0004 & 0.353 & $-2.7 \mathrm{E}-05$ & 0.860 & -0.002 & 0.317 \\
\hline Local agroecology kola & $0.089^{*}$ & 0.055 & $-0.210^{* * *}$ & 0.000 & $-0.128^{* * *}$ & 0.000 & -0.013 & 0.439 & $-0.023^{* *}$ & 0.014 & $0.285^{* * *}$ & 0.000 \\
\hline Local agroecology Dega & 0.050 & 0.208 & 0.049 & 0.320 & $-0.069^{* *}$ & 0.036 & 0.045 & 0.181 & -0.013 & 0.117 & -0.062 & 0.316 \\
\hline Temperature & $0.026^{* *}$ & 0.011 & $0.055^{* * *}$ & 0.001 & -0.011 & 0.475 & $0.012^{* *}$ & 0.035 & $0.006^{*}$ & 0.077 & $-0.089^{* * *}$ & 0.000 \\
\hline Precipitation & $-0.004^{* * *}$ & 0.000 & $-0.003^{* * *}$ & 0.000 & -0.0004 & 0.394 & $0.001^{* *}$ & 0.020 & $-0.0004^{* *}$ & 0.020 & $0.007^{* * *}$ & 0.000 \\
\hline
\end{tabular}

$* * *, *, *$ Significant at $1 \%, 5 \%$, and $10 \%$ probability level, respectively.

options (adaptation option in this case) such as soil conservation, use of different crop varieties and changing planting dates instead of planting trees which competes with the limited land available.

\subsection{Nonfarm income}

In addition to farm income, nonfarm income also significantly increases the likelihood of planting trees, changing planting dates, and using irrigation as adaptation options. A unit increase in nonfarm income increases the probability of planting tress and changing planting dates by 0.004 and $0.001 \%$, respectively. Nonfarm income showed a negative relationship with the adoption of soil conservation practices and the use of different crop varieties, although these results are not statistically significant. These indicate that when farmers have options for nonfarm incomes, farmers can afford to plant tress on the limited available land, can afford the cost of irrigation, and can use less of the agronomic practices such as soil conservation and the use of different crop varieties.

\subsection{Livestock ownership}

The ownership of livestock is also positively related to most of the adaptation options, even though the marginal impacts are not significant. It is positively related to the adoption of adaptation methods such as conserving soil, planting trees, and changing planting dates. Livestock ownership is negatively related to the use of different crop varieties and irrigation, although not significantly.

\subsection{Crop and livestock extension}

As expected, access to crop and livestock extension has a positive and significant impact on planting trees. Having access to crop and livestock production increases the probability of planting trees by $18 \%$. Planting trees counteracts different types of environmental damage and provides shade for livestock.

\subsection{Information on climate change}

Information on temperature and rainfall has a significant and positive impact on the likelihood of using different crop varieties: it increases the likelihood of using different crop varieties by $17.6 \%$.

\subsection{Access to credit}

Access to credit has a positive and significant impact on the likelihood of using soil conservation, changing planting dates, and using irrigation. This result implies the important role of increased institutional support in promoting the use of adaptation options to reduce the negative impact of climate change.

\subsection{Farmer-to-farmer extension}

Having access to farmer-to-farmer extension increases the likelihood of using different crop varieties by $11.3 \%$ and planting trees by $12 \%$. It also appears to increase the use of the other adaptation methods, although the results are not statistically significant.

\subsection{Number of relatives}

Having more relatives in the got is also positively related to the likelihood of adoption of most of the adaptation methods, although the coefficients are not statistically significant. The implication of this result is that social networks increase awareness and use of climate change adaptation options.

\subsection{Agroecological setting}

As expected, different farmers living in different agroecological settings employ different adaptation methods. For instance, farming in the kola zone significantly increases the probability of soil conservation by $8.9 \%$, compared with farming in weynadega. However, farming in kola significantly reduces the probability of using different crop varieties, planting trees, and irrigation by 21 , 13 and $2.3 \%$, respectively, compared with farming in weynadega. Moreover, farming in dega significantly decreases the probability of planting trees by $7 \%$, compared with farming in weynadega.

\subsection{Temperature}

Households with higher annual mean temperature over the survey period were more likely to adapt to climate change through the adoption of different practices. A rise in temperature one degree higher than the mean increases the probability of using soil 
conservation (2.6\%), different crop varieties (5.5\%), irrigation (0.6\%), and changing planting dates (1.2\%). These results indicate that, with more warming, farmers will conserve soil to preserve the moisture content and use drought-tolerant varieties to cope with increased temperature. Moreover, farmers will vary planting dates so that critical crop growth stages do not coincide with peak temperature periods, and they will irrigate to supplement rain water and to compensate for loss of water associated with increased evapo-transpiration due to increased temperature.

\subsection{Precipitation}

Unlike rising temperatures, higher levels of precipitation over the survey period appear to work in the opposite direction with regard to the likelihood of adoption of adaptation techniques. This indicates that increasing precipitation relaxes the constraints imposed by increased temperature on soil moisture content and thus crop growth. Conversely, the results of this analysis reconfirm that decreasing precipitation significantly increases the likelihood of using soil conservation, changing crop varieties, changing planting dates, and irrigating.

\section{Conclusions and policy implications}

The study analyzed the factors affecting the choice of adaptation methods to climate change based on a cross-sectional survey data collected during the 2004/2005 agricultural production year in the Nile basin of Ethiopia. The surveyed farmers were asked if they have observed any change in temperature and rainfall over the past 20 years. Those who responded to have observed changes over the past 20 years were asked if thy have responded to climatic conditions through adaptation. Those who could afford to adapt indicated that they undertake soil conservation, use different crop varieties, plant tress, change planting dates and irrigate their farms to reduce the negative impacts of climate change. Those who did not adapt mentioned lack of information on adaptation methods and financial constraints to using any of the adaptation methods.

The study uses the multinomial logit (MNL) model to investigate the factors guiding household choices of climate change adaptation methods. In the model, the dependent variables include different adaptation methods and the explanatory variables include different household, institutional, and social factors. The MNL was run and tested for the assumption of the independence of irrelevant alternatives (IIA) There was no evidence that this assumption was violated when the Heckman and the seemingly unrelated post-estimation procedures (SUEST) were run, justifying the application of the MNL specification to the data. More over, statistical testes indicated that there are no multiccolinearity and endogeniety problems in the fitted model.

The marginal effects from the MNL, which measure the expected change in probability of a particular choice being made with respect to a unit change in an independent variable, were presented for their ease of interpretation. The results from the marginal analysis indicate that household characteristics such as education, farm and nonfarm incomes which could be enhanced through policy intervention have significant impact on adaptation to climate change. Thus, investment in education systems, sufficient input supply which increases farm income and creation of off-farm employment opportunities in the rural areas can be underlined as a policy option in the reduction of the negative impacts of climate change.

The study further revealed that institutional factors such as extension on crop and livestock production, access to information on climate change and access to credit enhanced adaptation to climate change. Consequently, policies aiming at promoting adaptation to climate change need to emphasize the crucial role of providing information on better production techniques and on climate change (through extension) and creating the financial means through affordable credit schemes to enable farmers adapt to climate change.

Social capital which was represented by farmer-to-farmers extension and the number of relatives in local area also affect adaptation to climate change positively. Policy interventions which encourage informal social networks (financially or materially) can promote group discussions and better information flows and enhance adaptation to climate change. Moreover, farmers living at different agroecological settings used different adaptation methods. Thus, future policy has to aim at providing adaptation technologies through agroecology based research.

With increasing temperature, farmers adopt adaptation methods such as soil conservation, use of better adapted crop varieties, altering planting dates and use of irrigation. Thus, future policy which promotes soil conservation, research on use of new crop varieties and livestock species that are better suited to drier conditions, and promote irrigation can support farmers to better cope with climate change. Finally increased precipitation appears to relax the constraints imposed by drier conditions on soil moisture content, need of crops on critical growth periods. The likelihood of choosing irrigations appeared to decrease with increasing precipitation. This is inline with the conventional wisdom that increasing precipitation reduces the need for irrigation, but not conclusive in a broader context of Ethiopia's food insecurity and drought prone climatic conditions. This result could possibly explain the fact that increasing precipitation may reduce the need to irrigate the rain-fed small-scale farming dominated by farmers who own very small plots of land and faced with very low technological capacity to irrigate. Apart from this result, we believe that investment in large scale irrigation schemes can buffer farmers from dependence on food aid in times of crop failure due to drought.

\section{Acknowledgments}

This work is supported by BEAF under the project "Food and Water Security under Global Change: Developing Adaptive Capacity with a Focus on Rural Africa." The authors would like to thank Wisdom Akpalu, Elizabeth Bryan and Edward Keto for reviewing this report and giving constructive comments. The views expressed here are the authors' alone.

\section{References}

Adger, W.N., Huq, S., Brown, K., Conway, D., Hulme, M., 2003. Adaptation to climate change in the developing world. Progress in Development Studies 3, 179-195.

Asfaw, A., Admassie, A., 2004. The role of education on the adoption of chemical fertilizer under different socioeconomic environments in Ethiopia. Agricultural Economics 30 (3), 215-228.

Boko, M., Niang, I., Nyong, A., Vogel, C., Githeko, A., Medany, M., Osman-Elasha, B., Tabo, R., Yanda, P., 2007. In: Parry, M.L., Canziani, O.F., Palutikof, J.P., van der Linden, P.J., Hanson, C.E. (Eds.), Africa. Climate Change 2007: Impacts, Adaptation and Vulnerability. Contribution of Working Group II to the Fourth Assessment Report of the Intergovernmental Panel on Climate Change. Cambridge University Press, Cambridge UK, pp. 433-467.

Bradshaw, B., Dolan, H., Smit, B., 2004. Farm-level adaptation to climatic variability and change: crop diversification in the Canadian prairies. Climatic Change 67, 119-141.

CIMMYT (International Maize and Wheat Improvement Center), 1993. The Adoption of Agricultural Technology: A Guide for Survey Design. Economics Program, Mexico City, Mexico.

Croppenstedt, A., Demeke, M., Meschi, M.M., 2003. Technology adoption in the presence of constraints: the case of fertilizer demand in Ethiopia. Review of Development Economics 7 (1), 58-70.

CSA (Central Statistics Authority), 2004. The Federal Democratic Republic of Ethiopia Statistical abstract for 2003. CSA, Addis Ababa.

Deksyos, T., Abebe, T., 2006. Assessing the impact of climate change on the water resources of the lake Tana sub-basin using the watbal model. CEEPA Discussion 
Paper No. 30. Centre for Environmental Economics and Policy in Africa. University of Pretoria, Pretoria, South Africa.

Deressa, T., 2007. Measuring the economic impact of climate change on Ethiopian agriculture: Ricardian approach. World Bank Policy Research Paper No. 4342. World Bank, Washington, DC.

Franzel, S., 1999. Socioeconomic factors affecting the adoption potential of improved tree fallows in Africa. Agroforestry Systems 47 (1-3), 305-321.

Green, W.H., 2000. Econometric Analysis, 4th ed. Prentice-Hall, Upper Saddle River, NJ.

Hassan, R., Nhemachena, C., 2008. Determinants of African farmers' strategies for adapting to climate change: multinomial choice analysis. African Journal of Agricultural and Resource Economics 2 (1), 83-104.

Igoden, C., Ohoji, P., Ekpare, J., 1990. Factors associated with the adoption of recommended practices for maize production in the Lake Basin of Nigeria. Agricultural Administration and Extension 29 (2), 149-156.

IPCC (Intergovernmental Panel on Climate Change), 2001. Climate Change: The Scientific Basis. http://www.ipcc.ch (Accessed June 2006).

Isham, J., 2002. The effect of social capital on fertiliser adoption: evidence from Rural Tanzania. Journal of African Economies 11, 39-60.

Katungi, E.M., 2007. Social capital and technology adoption on small farms: the case of banana production technology in Uganda. Ph.D. Thesis. Department of Agricultural Economics, Extension, and Rural Development, University of Pretoria, South Africa.

Kebede, Y., Kunjal, K., Coffin, G., 1990. Adoption of new technologies in Ethiopian agriculture: the case of Tegulet-Bulga District, Shewa Province. Agricultural Economics 4, 27-43.

Kidane, G., Abebe, T., Degefie, T., 2006. Estimating crop water use and simulating yield reduction for maize and sorghum in Adama and Miesso districts using the cropwat model. CEEPA Discussion Paper No. 31. Centre for Environmental Economics and Policy in Africa. University of Pretoria, Pretoria, South Africa.

Kinfe, H., 1999. Impact of climate change on the water resources of Awash River Basin, Ethiopia. Climate Research 12, 91-96.

Knowler, D., Bradshaw, B., 2007. Farmers' adoption of conservation agriculture: a review and synthesis of recent research. Food Policy 32 (1), 25-48.

Kurukulasuriya, Mendelsohn, 2008. A Ricardian analysis of the impact of climate change on African cropland. African Journal of Agricultural and Resource Economics 2 (1), 1-23.

Lijalem, Z., Jackson, R., Dilnesaw, A.C., 2006. Climate change impact on Lake Ziway watershed's water availability, Ethiopia. Paper presented on the conference "Prosperity and Poverty in a Globalised World-Challenges for Agricultural Research", Tropentag, October 11-13, Bonn, Germany.

Lin, J., 1991. Education and innovation adoption in agriculture: evidence from hybrid rice in China. American Journal of Agricultural Economics 73 (3), 713-723.
Madalla, G., 1983. Limited Dependent and Qualitative Variables in Econometrics. Cambridge University Press, Cambridge.

Maddison, D., 2006. The perception of and adaptation to climate change in Africa. CEEPA. Discussion Paper No. 10. Centre for Environmental Economics and Policy in Africa. University of Pretoria, Pretoria, South Africa.

McCarthy, J., Canziani, O.F., Leary, N.A., Dokken, D.J., White, C. (Eds.), 2001. Climate Change 2001: Impacts, Adaptation, and Vulnerability. Contribution of Working Group II to the Third Assessment Report of the Intergovernmental Panel on Climate Change. Cambridge University Press, Cambridge.

MoWR (Ministry of Water Resources), 1998. Tekeze River Basin Integrated Development Master Plan Project. Executive Summary, FDRE [SPELL OUT] MoWR (Ministry of Water Resources), Addis Ababa.

Nhemachena, C., Hassan, R., 2007. Micro-level analysis of farmers' adaptation to climate change in Southern Africa. IFPRI Discussion Paper No. 00714. International Food Policy Research Institute, Washington, DC.

NMSA (National Meteorological Services Agency), 2001. Initial National Communication of Ethiopia to the United Nations Framework Convention on Climate Change (UNFCCC). NMSA, Addis Ababa, Ethiopia.

Norris, E., Batie, S., 1987. Virginia farmers' soil conservation decisions: an application of tobit analysis. Southern Journal of Agricultural Economics 19 (1), 89-97.

Pattanayak, S.K., Mercer, D.E., Sills, E., Jui-Chen, Y., 2003. Taking stock of agroforestry adoption studies. Agroforestry Systems 57 (3), 173-186.

Pearce, D., Cline, W., Achanta, A., Fankhauser, S., Pachauri, R., Tol, R., Vellinga, P. 1996. The social costs of climate change: greenhouse damage and benefits of control. In: Bruce, J., Lee, H., Haites, E. (Eds.), Climate Change 1995: Economic and Social Dimensions of Climate Change. Cambridge University Press, Cambridge.

Seo, N., Mendelsohn, R., 2008. Animal husbandry in Africa: climate change impacts and adaptations. African Journal of Agricultural and resource Economics 2 (1), $65-82$

Shiferaw, B., Holden, S., 1998. Resource degradation and adoption of land conservation technologies in the Ethiopian highlands: case study in Andit Tid, North Shewa. Agricultural Economics 27 (4), 739-752.

Tenge De Graaff, J., Hella, J.P., 2004. Social and economic factors affecting the adoption of soil and water conservation in West Usambara highlands, Tanzania. Land Degradation and Development 15 (2), 99-114.

Tse, Y.K., 1987. A diagnostic test for the multinomial logit model. Journal of Business and Economic Statistics 5 (2), 283-286.

Wooldridge, J.M., 2002. Econometric Analysis of Cross Section and Panel Data. MIT Press, Cambridge, MA.

Yirga, C.T., 2007. The dynamics of soil degradation and incentives for optimal management in Central Highlands of Ethiopia. Ph.D. Thesis. Department of Agricultural Economics, Extension, and Rural Development, University of Pretoria, South Africa. 